\title{
Response of alpine lakes and soils to changes in acid deposition: the MAGIC model applied to the Tatra Mountain region, Slovakia-Poland
}

\author{
Jiří KOPÁČEK*, David HARDEKOPF ${ }^{1)}$, Vladimír MAJER ${ }^{2)}$, Petra PŠENÁKOVÁ ${ }^{1)}$, Evžen STUCHLÍK ${ }^{1)}$ \\ and Josef VESELÝ ${ }^{2)}$ \\ Hydrobiological Institute, AS CR, and Faculty of Biological Sciences, USB, Na Sádkách 7, 37005 České Budějovice, Czech Republic \\ ${ }^{1)}$ Department of Hydrobiology, Charles University, Viničná 7, 12044 Praha 2, Czech Republic \\ ${ }^{2)}$ Czech Geological Survey, Geologická 6, 15200 Praha 5, Czech Republic \\ *e-mail corresponding author: jkopacek@hbu.cas.cz
}

\begin{abstract}
A dynamic process-based model of surface water acidification, MAGIC, was applied to 31 representative alpine lakes in the Tatra Mountains ( $50 \%$ of all alpine lakes $>0.3$ ha in the lake-district). The model was calibrated to observed lake chemistry for the period 1980-2002. Surface water and soil chemistry were reconstructed from 1860 to 2002, given estimates of historical acid deposition, and forecast to 2020 based on the reduction in sulphur and nitrogen emissions presupposed by the Gothenburg Protocol. In the 1860s, all lakes were buffered by the carbonate system and only $6 \%$ of lakes had acid neutralising capacity $\left(\right.$ ANC) $<20 \mu e q l^{-1}$. Lake acidification progressed until 1980s, at which time 23\% of lakes had a depleted carbonate buffering system and 33\% of lakes had ANC $<20 \mu \mathrm{eq} \mathrm{l}^{-1}$. Reversal of water chemistry from acidification started in the late 1980s as a response to decreasing acid deposition. ANC has increased such that only $\sim 16 \%$ of the lake population currently has ANC $<20 \mu e q l^{-1}$. The number of low ANC lakes is predicted to decrease to $10 \%$ by 2020, but the original carbonate buffering system of these lakes will not be re-established. The patterns in long-term changes of sulphate and chloride primarily reflected trends in atmospheric deposition and were similar for all lakes. Base cations $(B C), A N C$, nitrate, and $\mathrm{pH}$, however, were significantly influenced by catchment characteristics. The water chemistry response to changes in strong acid anion (SAA) inputs varied among the lakes. The changes in SAA were compensated for (1) by parallel changes in BC concentrations ( $75 \%$ of the SAA change) in non-sensitive lakes (high weathering rates and abundant soils with high base saturation), (2) by inverse changes in bicarbonate concentrations ( $>50 \%$ of the SAA change) in sensitive lakes with intermediate weathering rates and little soils (low BC exchangeable capacity and elevated terrestrial export of nitrate) and (3) by parallel changes in concentrations of protons and aluminium (each $20 \%$ of the SAA change) in extremely sensitive lakes, with the lowest weathering rates and soil base saturation. The full implementation of the Gothenburg Protocol will not be sufficient to allow recovery of the latter group of lakes, which will remain acidified after 2020.
\end{abstract}

Key words: atmospheric deposition, water chemistry, acidification, recovery

\section{INTRODUCTION}

Surface water acidification due to atmosphericallydeposited sulphur (S) and nitrogen $(\mathrm{N})$ compounds became a major ecosystem stress in acid sensitive regions over Europe during the 1900s. The adoption of four international protocols to reduce $\mathrm{S}$ and $\mathrm{N}$ emissions during the 1980s and 1990s (Jenkins 1999) led to a significant decrease in acid deposition and a widespread reversal of European surface waters from acidification (e.g., Evans et al. 2001; Jenkins et al. 2003). The last (Gothenburg) Protocol was signed in 1999, and when fully implemented by 2010 will significantly reduce emissions of $\mathrm{S}$ and both oxidised and reduced $\mathrm{N}$ compound across Europe (UN-ECE 1999).

In this study we apply a dynamic process-based model - MAGIC (Model of Acidification of Groundwater in Catchments; Cosby et al. 2001) - to reconstruct past acidification and predict recovery of lake water chemistry in the Tatra Mountains, one of the most severely acidified European alpine ecosystems. Such results should be relevant for decision-makers, in that they give an estimate of surface water recovery after full implementation of the Gothenburg Protocol.

The Tatra Mountain lakes have exhibited a pronounced long-term dynamic in nitrate concentrations and great differences in water chemistry due to their catchment characteristics (Kopáček et al. 2000). Thus, the MAGIC calibration of the lakes was site-specific and was first tested at four selected lakes (Kopáček et al. 2003). The successful approach was then applied to another 27 representative Tatra Mountain lakes. This study evaluates the modelled long-term trends in water chemistry of the Tatra Mountain lakes on a regional scale, compares the modelled and measured data, and simulates the future water response in the lake district given reductions in $\mathrm{S}$ and $\mathrm{N}$ deposition under the Gothenburg Protocol (UN-ECE 1999).

\section{METHODS}

\subsection{Data sources}

The Tatra Mountains belong to the Carpathian chain and are situated at the Slovak-Polish border $\left(20^{\circ} \mathrm{E}\right.$, 
Tab. 1. Major morphological and hydrological characteristics for the Tatra Mountain catchment-lake ecosystems. Numbers at lake names represent lake sensitivity to acidification: ${ }^{1)}$ non-sensitive; ${ }^{2)}$ sensitive; ${ }^{3)}$ extremely sensitive.

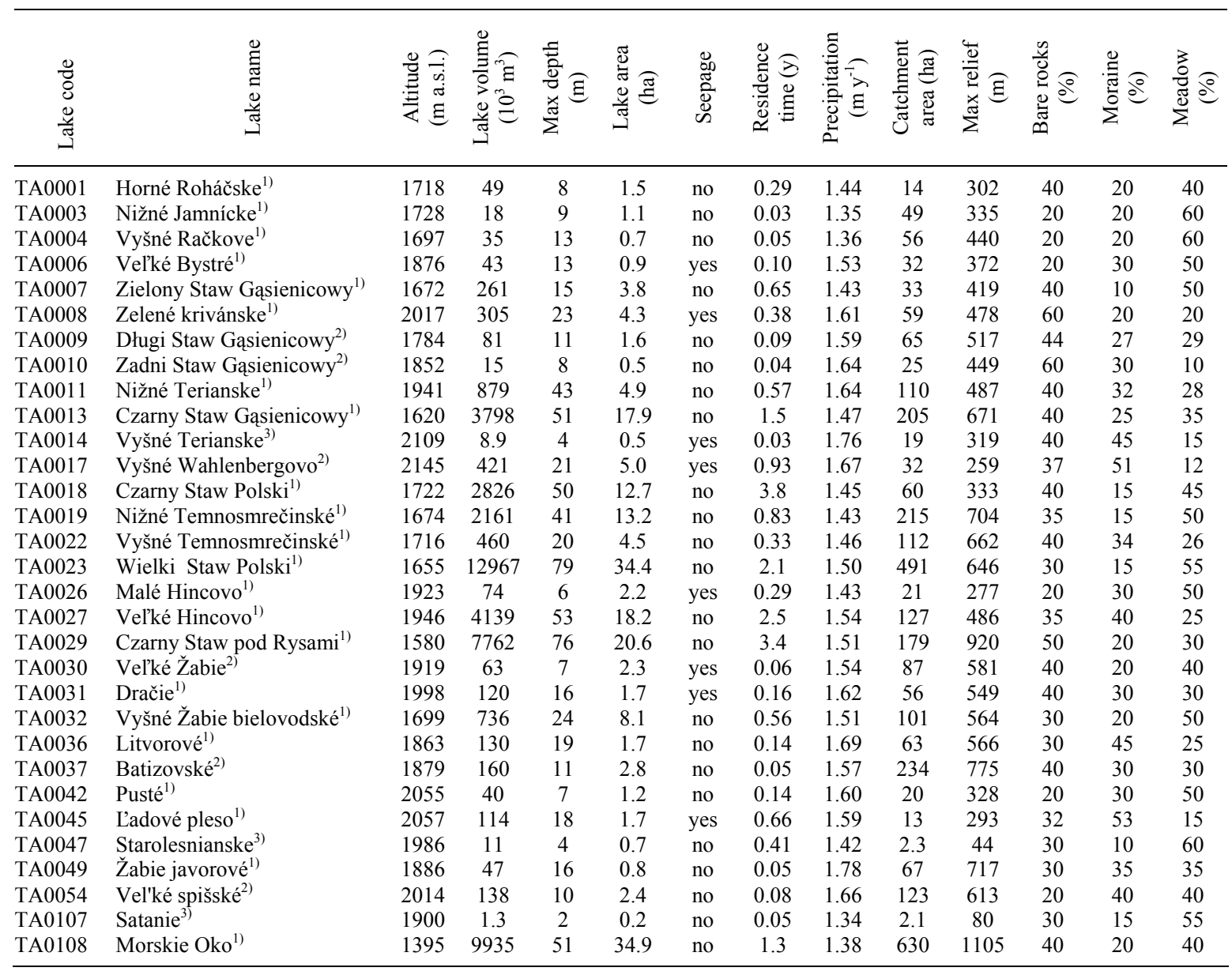

$\left.49^{\circ} 15^{\prime} \mathrm{N}\right)$. The total number of alpine Tatra Mountain lakes with an area $>0.3$ ha is 56 (other 28 lakes have an area $0.1-0.3 \mathrm{ha}$ ). All are perennial, of glacial origin, and situated in the western (the West Tatra Mountains) and central (the High Tatra Mountains) regions. For the purpose of this study we selected 31 lakes $(\sim 50 \%$ of all major alpine lakes $>0.3 \mathrm{ha}$ ) along the Tatra Mountains on the basis of previous studies (e.g., Kopáček et al. 2000), so that the selected lakes were representative for the alpine zone both regionally (geographic position; altitude) and morphologically (dominant land cover in the catchment). Thirty lakes are situated between 1580 and $2145 \mathrm{~m}$ above sea level (a.s.l.) and the highest points of their catchments range from 1980 to $2654 \mathrm{~m}$ a.s.l. Among them, only lake TA0107 has an area $<0.3$ ha. One lake (Morskie Oko, TA0108) is situated below the local tree line at an altitude of $1395 \mathrm{~m}$ a.s.l., but most of its catchment lies in the alpine zone. Consequently, its chemistry is comparable with the other alpine Tatra Mountain lakes and differs significantly from the forest lakes in the region. The lake was included in this study due to its extensive historical record of water chemistry. Major morphological characteristics and numerical codes of selected lakes are given in table 1 .
Vegetation of the alpine zone of the Tatra Mountains is dominated by alpine meadows (dry tundra with mostly Calamagrostis villosa, Festuca picta, and Luzula luzuloides), with patches of dwarf pine (Pinus mugo), and an increasing percentage of rocks (bare or covered with lichens - commonly Rhizocarpon, Acarospora oxytona, and Dermatocarpon luridum) above the upper tree line of $1800 \mathrm{~m}$ a.s.l. (Vološčuk 1994).

Geological characteristics were estimated by using a 1:50,000 map (Nemčok et al. 1993). The bedrock geology of the High Tatra Mountains is composed almost exclusively of granitoids (mostly biotite granodiorites to tonalites), while the West Tatra Mountains also contain a significant amount of metamorphics (gneiss and mica schist) in addition to granodiorite.

Data on soil come from a 1998-2001 survey (Stuchlík et al. 2002; Kopáček et al. 2004). Alpine soils (in meadows) are mostly regosols, leptosols, podsols, and cambisols, with negligible carbonate content. Soil depth and amount of dry weight $<2 \mathrm{~mm}$ soil vary from 0.1 to $0.84 \mathrm{~m}$ and from 38 to $255 \mathrm{~kg} \mathrm{~m}^{-2}$, with averages of 0.45 $\mathrm{m}$ and $121 \mathrm{~kg} \mathrm{~m}^{-2}$, respectively. Soil $\mathrm{pH}$ is generally low, with $\mathrm{pH}_{\mathrm{CaCl} 2}$ within the 3.2-4.2 range in organic and 3.6-4.8 range in mineral horizons. The cation ex- 
Tab. 2. Major soil (dry, $<2 \mathrm{~mm}$ ) and water characteristics for the Tatra Mountain catchment-lake ecosystems. For lake names see table 1. Measured soil data $(*)$. Soil pool, dry weight $<2 \mathrm{~mm}$ soil fraction; $\mathrm{CEC}$, cation exchangeable capacity $(1 \mathrm{M} \mathrm{NH} \mathrm{Nl}$ extractable $\mathrm{Ca}^{2+}, \mathrm{Mg}^{2+}, \mathrm{Na}^{+}$, and $\mathrm{K}^{+}$plus $1 \mathrm{M} \mathrm{KCl}$ extractable $\mathrm{Al}^{3+}$ and $\mathrm{H}^{+}$); BS, base saturation; C-org, organic carbon.

\begin{tabular}{|c|c|c|c|c|c|c|c|c|c|c|c|c|c|c|c|c|c|}
\hline \multirow[b]{2}{*}{ 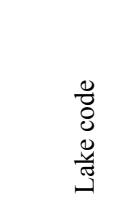 } & \multicolumn{5}{|c|}{ Soil characteristics } & \multicolumn{12}{|c|}{ Water characteristics (1997-2000 average) } \\
\hline & 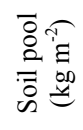 & 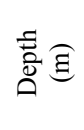 & 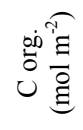 & 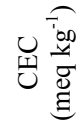 & 吕 $\widehat{a}$ & 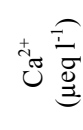 & 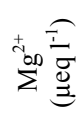 & 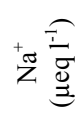 & 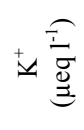 & 氞尌 & 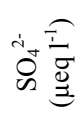 & $\dot{\widetilde{I}}$ & 它突 & 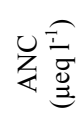 & 兑 & 宗 & 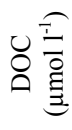 \\
\hline TA0001* & 44 & 0.20 & 332 & 123 & 9 & 102 & 11 & 15 & 3.0 & 0.9 & 58 & 4.2 & 25 & 39 & 6.33 & 0.19 & 46 \\
\hline TA0003* & 64 & 0.41 & 228 & 107 & 7 & 155 & 101 & 22 & 2.6 & 0.5 & 73 & 5.2 & 18 & 188 & 7.07 & $<0.01$ & 33 \\
\hline TA0004* & 77 & 0.24 & 137 & 53 & 15 & 163 & 145 & 22 & 2.7 & 0.6 & 67 & 4.8 & 19 & 235 & 7.07 & 0.01 & 29 \\
\hline TA0006* & 46 & 0.18 & 389 & 116 & 14 & 299 & 79 & 21 & 3.3 & 4.3 & 55 & 6.0 & 26 & 314 & 7.13 & $<0.01$ & 83 \\
\hline TA0007 & 62 & 0.23 & 352 & 98 & 12 & 134 & 16 & 22 & 3.4 & 0.9 & 51 & 4.5 & 17 & 98 & 6.76 & $<0.01$ & 67 \\
\hline TA0008 & 27 & 0.09 & 147 & 95 & 12 & 133 & 7 & 23 & 2.7 & 2.9 & 49 & 4.2 & 29 & 80 & 6.71 & $<0.01$ & 25 \\
\hline TA0009* & 33 & 0.11 & 136 & 91 & 11 & 90 & 8 & 15 & 2.8 & 1.5 & 52 & 3.8 & 35 & 21 & 6.11 & 0.07 & 16 \\
\hline TA0010* & 15 & 0.05 & 63 & 79 & 13 & 103 & 8 & 18 & 2.0 & 1.9 & 48 & 3.8 & 44 & 37 & 6.38 & 0.00 & 20 \\
\hline TA0011* & 51 & 0.13 & 296 & 86 & 8 & 139 & 7 & 14 & 2.4 & 0.8 & 45 & 4.1 & 28 & 82 & 6.69 & $<0.01$ & 25 \\
\hline TA0013 & 45 & 0.16 & 253 & 96 & 12 & 113 & 11 & 15 & 3.1 & 1.1 & 58 & 5.7 & 36 & 34 & 6.24 & $<0.01$ & 43 \\
\hline TA0014* & 52 & 0.14 & 280 & 94 & 7 & 41 & 5 & 8 & 2.2 & 0.8 & 35 & 3.1 & 25 & -4 & 5.13 & 2.67 & 56 \\
\hline TA0017* & 22 & 0.08 & 79 & 72 & 11 & 83 & 8 & 9 & 1.7 & 0.8 & 37 & 4.4 & 29 & 26 & 6.20 & 0.03 & 14 \\
\hline TA0018 & 56 & 0.20 & 319 & 98 & 12 & 114 & 10 & 16 & 2.6 & 0.8 & 50 & 5.0 & 19 & 61 & 6.47 & $<0.01$ & 62 \\
\hline TA0019 & 62 & 0.23 & 354 & 98 & 12 & 274 & 24 & 17 & 2.6 & 2.0 & 54 & 4.9 & 22 & 216 & 7.01 & $<0.01$ & 30 \\
\hline TA0022* & 28 & 0.10 & 283 & 126 & 9 & 294 & 28 & 17 & 2.7 & 3.0 & 52 & 4.5 & 20 & 252 & 7.05 & $<0.01$ & 17 \\
\hline TA0023 & 68 & 0.25 & 389 & 98 & 12 & 122 & 10 & 16 & 2.5 & 0.9 & 48 & 4.2 & 21 & 71 & 6.63 & $<0.01$ & 38 \\
\hline TA0026* & 44 & 0.24 & 160 & 95 & 16 & 306 & 85 & 15 & 2.3 & 1.1 & 110 & 3.8 & 17 & 276 & 7.18 & $<0.01$ & 55 \\
\hline TA0027* & 50 & 0.15 & 377 & 114 & 12 & 165 & 15 & 14 & 2.3 & 0.3 & 58 & 4.3 & 29 & 102 & 6.76 & 0.01 & 29 \\
\hline TA0029 & 39 & 0.14 & 216 & 96 & 12 & 212 & 14 & 16 & 2.6 & 0.7 & 69 & 4.7 & 32 & 133 & 6.91 & $<0.01$ & 31 \\
\hline TA0030 & 51 & 0.18 & 286 & 97 & 12 & 104 & 7 & 11 & 2.2 & 1.5 & 49 & 4.3 & 32 & 35 & 6.22 & $<0.01$ & 13 \\
\hline TA0031 & 40 & 0.14 & 220 & 95 & 12 & 176 & 11 & 15 & 2.0 & 1.4 & 55 & 3.9 & 33 & 111 & 6.70 & $<0.01$ & 4 \\
\hline TA0032* & 51 & 0.25 & 344 & 139 & 10 & 109 & 8 & 15 & 2.2 & 1.5 & 54 & 3.5 & 22 & 46 & 6.31 & $<0.01$ & 36 \\
\hline TA0036 & 36 & 0.11 & 191 & 92 & 12 & 165 & 13 & 16 & 2.0 & 1.0 & 50 & 2.9 & 31 & 109 & 6.86 & $<0.01$ & 12 \\
\hline TA0037 & 40 & 0.14 & 220 & 95 & 12 & 99 & 8 & 16 & 2.4 & 0.7 & 54 & 4.2 & 30 & 29 & 6.21 & 0.04 & 12 \\
\hline TA0042 & 64 & 0.23 & 359 & 97 & 12 & 169 & 12 & 14 & 2.8 & 1.6 & 46 & 2.6 & 21 & 130 & 6.88 & $<0.01$ & 23 \\
\hline TA0045* & 29 & 0.06 & 109 & 74 & 20 & 110 & 7 & 11 & 1.7 & 1.6 & 35 & 3.8 & 23 & 67 & 6.57 & 0.03 & 12 \\
\hline TA0047* & 100 & 0.29 & 489 & 99 & 8 & 29 & 6 & 9 & 3.9 & 1.8 & 43 & 3.5 & 4 & -2 & 5.27 & 0.95 & 103 \\
\hline TA0049 & 47 & 0.16 & 257 & 95 & 12 & 209 & 13 & 16 & 2.0 & 1.9 & 68 & 3.2 & 40 & 131 & 6.99 & 0.00 & 8 \\
\hline TA0054 & 53 & 0.18 & 294 & 95 & 12 & 76 & 6 & 8 & 1.1 & 0.1 & 36 & 3.7 & 29 & 20 & 6.08 & $<0.01$ & 14 \\
\hline TA0107 & 68 & 0.25 & 389 & 97 & 12 & 28 & 7 & 11 & 3.4 & 1.5 & 50 & 4.4 & 10 & -8 & 4.96 & 6.33 & 91 \\
\hline TA0108 & 51 & 0.18 & 286 & 97 & 12 & 189 & 14 & 19 & 3.2 & 1.2 & 64 & 4.9 & 26 & 128 & 6.82 & 0.01 & 41 \\
\hline
\end{tabular}

changeable capacity $\left(1 \mathrm{M} \mathrm{NH}_{4} \mathrm{Cl}\right.$ extractable $\mathrm{Ca}^{2+}, \mathrm{Mg}^{2+}$, $\mathrm{Na}^{+}$, and $\mathrm{K}^{+}$plus $1 \mathrm{M} \mathrm{KCl}$ extractable $\mathrm{Al}^{3+}$ and $\mathrm{H}^{+}$) of alpine soils varies between 20 and $207 \mathrm{meq} \mathrm{kg}^{-1}$ (all horizons) and is dominated by exchangeable $\mathrm{Al}^{3+}(70 \%$ on average). The base saturation of soils is $4-45 \%(12 \%$ on average) of the cation exchangeable capacity, and is primarily based on $\mathrm{Ca}^{2+}(\sim 40 \%)$. The till soils in moraine areas form thin $(<3 \mathrm{~cm}$ deep) layers covered by a $20-60 \mathrm{~cm}$ thick layer of surface stones, or lenses between stones. Pools of the till soils vary between 4-33 $\mathrm{kg} \mathrm{m}^{-2}$, with an average of $13 \mathrm{~kg} \mathrm{~m}^{-2}(<2 \mathrm{~mm}$; dried weight), and their chemical composition is similar to mineral layers of alpine soils.

The soil data used in this study were measured in 15 catchments (lakes with asterisks in table 2). The mean physical-chemical composition of the meadow soil profile was calculated for each catchment, but that for the moraine class was averaged across all catchments. These soil characteristics were then used to calculate a catchment-weighted mean soil amount (and composition) using the proportion of alpine meadows and moraine areas in the catchment area. The areas of land cover classes (Tab. 1) were estimated by using a 1:25,000 map, planimetry of photographs, and field observations. The soil data for 16 other catchments were derived from their land cover characteristics and the average pools and mean composition of the meadow and till Tatra Mountain soils (Tab. 2).

Data on lake water chemistry come from: (i) Stangenberg (1938) for $1937\left(\mathrm{SO}_{4}{ }^{2-}, \mathrm{NO}_{3}{ }^{-}\right)$, (ii) Bombówna (1965) and Procházková (unpubl. data) for 1963 and 1961, respectively (pH, $\mathrm{SO}_{4}{ }^{2-}, \mathrm{NO}_{3}{ }^{-}$), (iii) Stuchlík et al. (1985; unpubl. data) and Bombówna \& Wojtan (1996) for 1980-1984 and 1985, respectively, (iv) Henriksen et al. (1992), Kopáček \& Stuchlík (1994), Kopáček et al. (2002) and Stuchlík (unpubl. data) for the1986-2002 period. No reliable historical data are available for acid neutralising capacity (ANC) and base cations (BC; sum of $\mathrm{Ca}^{2+}, \mathrm{Mg}^{2+}, \mathrm{Na}^{+}$, and $\mathrm{K}^{+}$) before the 1980s or for $\mathrm{pH}$ before the 1960s. Since the 1980s, the lakes have been sampled once a year in September-October. In the 19801992 period, anions were determined colorimetrically and/or by capillary isotachophoresis, and $\mathrm{BC}$ and $\mathrm{Al}$ by atomic absorption spectrophotometry and/or inductively 
coupled plasma atomic emission spectrometry. Since 1992, concentrations of major ions have been analysed by ion chromatography and $\mathrm{Al}$ colorimetrically according to Driscoll (1984). ANC has been determined by Gran titration since 1980. Positive ANC is given as $\mathrm{HCO}_{3}{ }^{-}$concentration. Dissolved organic carbon (DOC) was analysed using a TOC 5000A analyser (Shimadzu). More details on analytical methods used for analyses before and after 1992 are given by Kopáček \& Stuchlík (1994) and Kopáček et al. (2000), respectively.

The long-term average annual precipitation amount was derived for individual catchments from the following sources: (i) the 1941-2001 average precipitation at Skalnaté Pleso (1.34 $\mathrm{m}$ at $1778 \mathrm{~m}$ a.s.l.; southern part of the central massif; data of the Geophysical Institute of the Slovak Academy of Sciences), and (ii) the elevation gradient of catchment, assuming increasing precipitation proportionally to altitude by 40 and $70 \mathrm{~mm}$ per $100 \mathrm{~m}$ of elevation in the southern and northern part of the mountain range, respectively (Chomitz \& Šamaj 1974). The resulting data (Tab. 1) were used as constants for the whole study period. The specific outflow in the alpine zone of the Tatra Mountains was estimated at $85 \%$ of the deposition (Lajczak 1996).

The 1860-2000 trends in bulk deposition of $\mathrm{SO}_{4}{ }^{2-}$, $\mathrm{NH}_{4}^{+}$, and $\mathrm{NO}_{3}^{-}$in the Tatra Mountains come from Kopáček et al. (2001) and were based on the following data sources: (i) the measured current deposition at Starolesnianske Lake (southern part; $2000 \mathrm{~m}$ a.s.1.) in 1997-2000 (Stuchlík et al. 2002; unpubl. data) and at Hala Gasienicowa (northern part; $1520 \mathrm{~m}$ a.s.l.) in 1993-1998 (Lydersen et al. 1997; The MOLAR Chemistry Group 1999), (ii) the long-term trend (1978-2000) in bulk deposition in northern Slovakia (Chopok station, situated $\sim 40 \mathrm{~km}$ south west of the Tatra Mountains at an elevation of $2008 \mathrm{~m}$; data of the Slovak Hydrometeorological Institute), and (iii) $\mathrm{S}$ and $\mathrm{N}$ emission rates in central Europe (Kopáček et al. 2001). The deposition scenario used for the future (2000-2020) predictions, has a decreasing trend until 2010 and then is constant until 2020. The changes in deposition of S and $\mathrm{N}$ compounds within the 2000-2010 period were assumed to be proportional to the changes in their respective emission levels in central Europe as required by the Gothenburg Protocol (UN-ECE 1999). Trends in deposition of $\mathrm{Cl}^{-}$ and $\mathrm{BC}$ were the sums of their background values (3.6 and $21 \mathrm{meq} \mathrm{m}^{-2} \mathrm{y}^{-1}$, respectively) and contributions from industrial sources, which were assumed to be proportional to $\mathrm{S}$ emissions in the region (Kopáček et al. 2003). The respective dry deposition of $\mathrm{SO}_{4}{ }^{2-}, \mathrm{NH}_{4}{ }^{+}$, and $\mathrm{NO}_{3}{ }^{-}$in the Tatra Mountains (13.2, 7.1, and 11.6 meq $\mathrm{m}^{-2} \mathrm{y}^{-1}$; Lydersen et al. 1997) represented $19 \%$, $16 \%$, and $36 \%$ of their bulk deposition in 1995-1996. These values were used to estimate trends in dry deposition factors, which varied between 1.0 and 1.2 for $\mathrm{SO}_{4}{ }^{2-}, \mathrm{NH}_{4}{ }^{+}, \mathrm{Cl}^{-}$and $\mathrm{BC}$, and between 1.0 and 1.35 for $\mathrm{NO}_{3}{ }^{-}$. The highest dry deposition factors were applied for the 1970s and 1980s, and lower values (proportional to the bulk deposition levels) before 1970 and after 2000 (Kopáček et al. 2003). Then, the total deposition was the product of bulk deposition and dry deposition factor (Fig. 1).

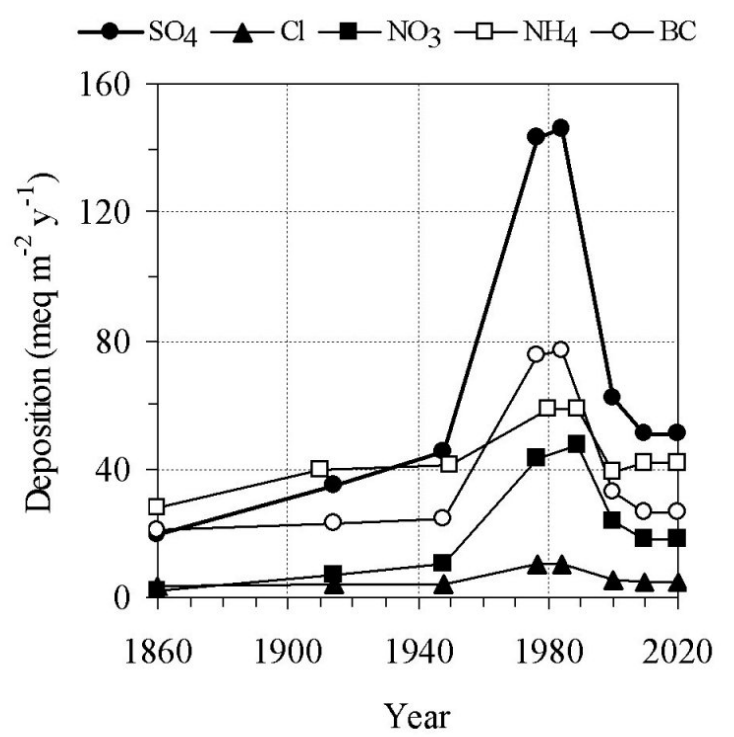

Fig. 1. Long-term trends in total deposition of $\mathrm{SO}_{4}{ }^{2-}, \mathrm{NO}_{3}{ }^{-}, \mathrm{Cl}^{-}$, base cations (BC), and $\mathrm{NH}_{4}{ }^{+}$in the Tatra Mountains used for MAGIC modelling. Data were derived from Kopáček et al. (2003).

The deposition sequences used in this study were successfully applied for MAGIC modelling of four lakes in the Tatra Mountains (Kopáček et al. 2003). In general, they have similar shapes to the deposition sequences derived for the region from the EMEP Lagrangian acid deposition model by Schöpp et al. (2003), but they are lower and have a broader peak of maximum $\mathrm{N}$ deposition in the 1970s and 1990s (consistent with the measured data at the nearby Chopok station; Kopáček et al. 2001).

\subsection{Model calibration}

The MAGIC (version 7) model by Cosby et al. (2001) was calibrated individually to each lake using the average atmospheric deposition for the 1997-2000 period, lake water chemistry for the 1997-2002 period, and soil chemistry for the 1998-2001 period (Tab. 2). The calibrations at each site proceeded by the following sequential steps:

1) Trends in the total deposition of $\mathrm{SO}_{4}{ }^{2-}, \mathrm{Cl}^{-}, \mathrm{NO}_{3}{ }^{-}$, $\mathrm{NH}_{4}{ }^{+}$, and $\mathrm{BC}$ into the catchments were applied as shown in figure 1.

2) Fixed parameters (Tab. 3): Dissociation constants of tri-protic organic acids, the $\mathrm{Al}(\mathrm{OH})_{3}$ solubility, and stability constants of organic-Al complexes (K(AlA) and $\mathrm{K}\left(\mathrm{AlHA}^{+}\right)$) were set according to Majer et al. (2003), where the modelled concentrations reasonably 
Tab. 3. Fixed parameters (measured* or estimated) for the Tatra Mountain lakes and catchment soils used in calibration of MAGIC. ${ }^{1)}$ Estimated and tested by Majer et al. (2003) and Kopáček et al. (2003).

\begin{tabular}{|c|c|c|c|}
\hline Parameter & For water or soil & Units & All lakes \\
\hline Temperature* & soil and water & ${ }^{\circ} \mathrm{C}$ & $2-3$ \\
\hline \multirow[t]{2}{*}{ Organic acid anions } & water & $\mathrm{mmol} \mathrm{m}^{-3}$ & $0.2-4.9$ \\
\hline & soill $^{1)}$ & $\mathrm{mmol} \mathrm{m}^{-3}$ & 85 \\
\hline \multirow[t]{2}{*}{$\mathrm{CO}_{2}$ partial pressure } & water & $\%$ & $0.04-0.08$ \\
\hline & soil & $\%$ & 0.4 \\
\hline $\mathrm{pK}_{1}$ (organic acids) & soil and water & $-\log$ & 2.6 \\
\hline $\mathrm{pK}_{2}$ (organic acids) & soil (water) & $-\log$ & $5.66(5.8)$ \\
\hline $\mathrm{pK}_{3}$ (organic acids) & soil (water) & $-\log$ & $5.94(7.0)$ \\
\hline Solubility $\mathrm{Al}(\mathrm{OH})_{3}$ & soil and water & $\log$ & 9.0 \\
\hline $\mathrm{SO}_{4}{ }^{2-}$ ads. maximum-capacity & soil & meq $\mathrm{kg}^{-1}$ & 12 \\
\hline $\mathrm{SO}_{4}^{2-}$ ads. half-saturation & soil & meq $\mathrm{m}^{-3}$ & 100 \\
\hline $\mathrm{K}(\mathrm{AlA})$ & water & $\log$ & 8.5 \\
\hline $\mathrm{K}\left(\mathrm{AlHA}^{+}\right)$ & water & $\log$ & 10 \\
\hline
\end{tabular}

Tab. 4. Median values and ranges of calibrated parameters for the Tatra Mountain lakes obtained from MAGIC. Number of observations, 31 .

\begin{tabular}{|c|c|c|c|c|c|c|}
\hline & Units & Minimum & $25 \%$ & Median & $75 \%$ & Maximum \\
\hline \multicolumn{7}{|c|}{ Cation exchange selectivity coefficients } \\
\hline $\mathrm{Al}-\mathrm{Ca}$ & $\log$ & -1.7 & 1.1 & 2.7 & 6.8 & 10.7 \\
\hline $\mathrm{Al}-\mathrm{Mg}$ & Log & -2.0 & -1.0 & 0.4 & 4.6 & 10.1 \\
\hline $\mathrm{Al}-\mathrm{Na}$ & Log & -6.1 & -5.1 & -3.7 & -2.5 & 0.2 \\
\hline Al-K & $\log$ & -7.6 & -7.2 & -6.2 & -4.7 & -2.8 \\
\hline \multicolumn{7}{|c|}{ Weathering rates } \\
\hline $\mathrm{Ca}^{2+}$ & meq $\mathrm{m}^{-2} \mathrm{y}^{-1}$ & 12 & 100 & 122 & 194 & 363 \\
\hline $\mathrm{Mg}^{2+}$ & meq $\mathrm{m}^{-2} \mathrm{y}^{-1}$ & 3 & 5 & 8 & 15 & 126 \\
\hline $\mathrm{Na}^{+}$ & meq $\mathrm{m}^{-2} \mathrm{y}^{-1}$ & 2 & 7 & 10 & 12 & 19 \\
\hline $\mathrm{K}^{+}$ & meq $\mathrm{m}^{-2} \mathrm{y}^{-1}$ & 0.1 & 0.2 & 0.3 & 0.6 & 1.4 \\
\hline \multicolumn{7}{|c|}{ Initial base saturation (1860) } \\
\hline $\mathrm{Ca}$ & $\%$ & 2.3 & 6.0 & 8.2 & 9.8 & 21.2 \\
\hline $\mathrm{Mg}$ & $\%$ & 1.0 & 2.3 & 2.9 & 3.3 & 4.1 \\
\hline $\mathrm{Na}$ & $\%$ & 0.6 & 2.6 & 3.1 & 3.5 & 4.4 \\
\hline $\mathrm{K}$ & $\%$ & 1.3 & 1.9 & 2.2 & 2.4 & 2.7 \\
\hline
\end{tabular}

equalled the observed lake water concentrations of ionic and organic $\mathrm{Al}$ forms and organic acid anions.

3) Net annual removal of $\mathrm{NO}_{3}^{-}$in the lakes was estimated according to Kelly et al. (1987), with the mass transfer coefficient $\left(5.0 \mathrm{~m} \mathrm{y}^{-1}\right)$ set at a lower range of values given by Kaste $\&$ Dillon (2002). Because the bottoms of some lakes are partly covered with rocks and big boulders, the above results were reduced proportionally to the per cent cover of bottom with sediment. The area of sediment was estimated at the lakes, and varied between $10 \%$ and $100 \%$ of the lake area. For lakes with no information on sediment cover a value of $50 \%$ was used. Estimated values of in-lake removal of $\mathrm{NO}_{3}^{-}(1-65 \%$ of the loading) were held constant for the whole period. Net annual removal of $\mathrm{SO}_{4}{ }^{2-}$ in the lakes $(1-14 \%$ of its loading), estimated according to Kelly et al. (1987) was too low for seepage lakes to satisfactorily model maxima in $\mathrm{SO}_{4}{ }^{2-}$ concentrations in the 1980 s or the current lowered concentrations (Kopáček et al. 2003). Consequently, the values of in-lake $\mathrm{SO}_{4}{ }^{2-}$ removal were fitted during the calibration process and were used in the range of $1-30 \%$.
Moreover, the fitted values represented a correction for uncertainties associated with $\mathrm{S}$ dynamics within the whole catchment-lake ecosystems. We assumed that the fitted percent in-lake removal of $\mathrm{SO}_{4}{ }^{2-}$ was stable throughout the study period. Net annual retention of BC in the lakes was neglected.

4) The soil sulphate chemistry was fitted in the calibration procedure such that modelled concentration equalled the measured in-lake concentrations of $\mathrm{SO}_{4}{ }^{2-}$ in the $1980 \mathrm{~s}$ and $1990 \mathrm{~s}$, because the measured adsorption data (1.6 to 4.6 meq $\mathrm{kg}^{-1}$ ) were too low (Kopáček et al. 2003). The fitted $\mathrm{SO}_{4}{ }^{2-}$ maximum adsorption capacity, which reasonably simulated the observed trends in water chemistry, was 12 meq $\mathrm{kg}^{-1}$, and was used for all catchments. The used $\mathrm{SO}_{4}{ }^{2-}$ adsorption half saturation was $100 \mathrm{meq} \mathrm{m}^{-3}$.

5) In the model, net catchment retention of $\mathrm{N}$ was roughly set as a function of time and catchment characteristics as follows: (i) For the 1860-1945 period, $100 \%$ uptake of $\mathrm{NO}_{3}{ }^{-}$was assumed only in the part of catchment covered with meadows and $100 \%$ uptake of $\mathrm{NH}_{4}^{+}$was assumed in the whole catchment. (ii) For the $1955-2020$ period, 100\% uptake of 
$\mathrm{NH}_{4}^{+}$and $\mathrm{NO}_{3}^{-}$was assumed only in the part of catchment covered with meadows. (iii) For the 1945-1955 period, linear interpolation was used between the previous and following periods. The $\mathrm{NO}_{3}{ }^{-}$entering the lake originated from $\mathrm{NO}_{3}{ }^{-}$and $\mathrm{NH}_{4}{ }^{+}$deposition on the rocky and moraine areas. We assumed that all $\mathrm{NH}_{4}{ }^{+}$deposited to these parts of the catchment was nitrified but not retained in the soils (Kopáček et al. 2003). These adjustments to the $\mathrm{N}$ parameters were needed in order to adequately calibrate the model to observed changes in $\mathrm{NO}_{3}^{-}$concentrations.

6) Weathering rates, cation exchange selectivity coefficients for base cations, and the original base saturation of soils were determined by a trial-and-error procedure such that the modelled pools and concentrations equalled the measured soil exchange pools and lake chemistry concentrations of each base cation for the 1998-2001 period (Tab. 4). The obtained rates and coefficients were applied as constants for the whole study period. The vegetation net uptake of $\mathrm{BC}$ and long-term net $\mathrm{BC}$ storage in biomass was set equal to zero as there is no removal of biomass from the catchments.

\section{RESULTS AND DISCUSSION}

\subsection{Simulated and observed trends in water composition}

The model was successfully calibrated for all 31 lakes and the simulated concentrations of $\mathrm{SO}_{4}{ }^{2-}, \mathrm{NO}_{3}{ }^{-}$, $\mathrm{ANC}, \mathrm{BC}$, and $\mathrm{pH}$ reasonably fitted the available observed data on lakes not only for the calibration years (1997-2002) but also for the 1937-1996 period, explaining $83-97 \%$ of their observed variability (Fig. 2). The simulated median composition of the alpine Tatra Mountain lakes was 21, 101, and $124 \mu \mathrm{eq} \mathrm{^{-1 }}$ for strong acid anions ( $\left.\mathrm{SAA}=\mathrm{SO}_{4}{ }^{2-}+\mathrm{NO}_{3}^{-}+\mathrm{Cl}^{-}\right), \mathrm{HCO}_{3}^{-}$, and $\mathrm{BC}$, respectively, in the 1860s (Tab. 5). The background SAA concentrations varied within relatively low ranges (Fig. 3), with the exception of $\mathrm{SO}_{4}{ }^{2-}$ in lake TA0026 which also has high current $\mathrm{SO}_{4}{ }^{2-}$ concentrations (Tab. 2). This lake has high background $\mathrm{SO}_{4}{ }^{2-}$ concentrations $\left(66 \mu\right.$ eq $\left.\mathrm{l}^{-1}\right)$ due probably to the weathering of S-bearing minerals in the bedrock; the soil S concentrations and pools are comparable to those in other catchments (Kopáček et al. 2004). The background values of $\mathrm{pH}$ and ANC varied within wider ranges than those of SAA (Fig. 3) and were tightly related to the $\mathrm{BC}$ concentrations. The simulated background relationship between $\mathrm{ANC}$ and $\mathrm{BC}$ was: $\mathrm{ANC}=0.95 \times \mathrm{BC}-17$ (all units are $\mu$ eq $\mathrm{l}^{-1} ; \mathrm{R}=0.99$ ). In the $1860 \mathrm{~s}$, all lakes still had a carbonate buffering system, and only $6 \%$ of the lake population had $\mathrm{ANC}<20 \mu \mathrm{eq} \mathrm{l}^{-1}$ and $\mathrm{pH}<6.0$ (Fig. 3).

The chemical composition of the lakes changed relatively little before the onset of major acidification in the $1950 \mathrm{~s}$, with the exception of $\mathrm{pH}$ in lakes with low background ANC (see below). SAA concentrations then increased rapidly to their maxima in the 1980s (Tab. 5), at which time $80 \%$ of lakes had concentrations of $\mathrm{SO}_{4}{ }^{2-}$ $>90 \mu$ eq $1^{-1}$ and $\mathrm{NO}_{3}{ }^{-}>25 \mu$ eq $1^{-1}$ (Fig. 3).
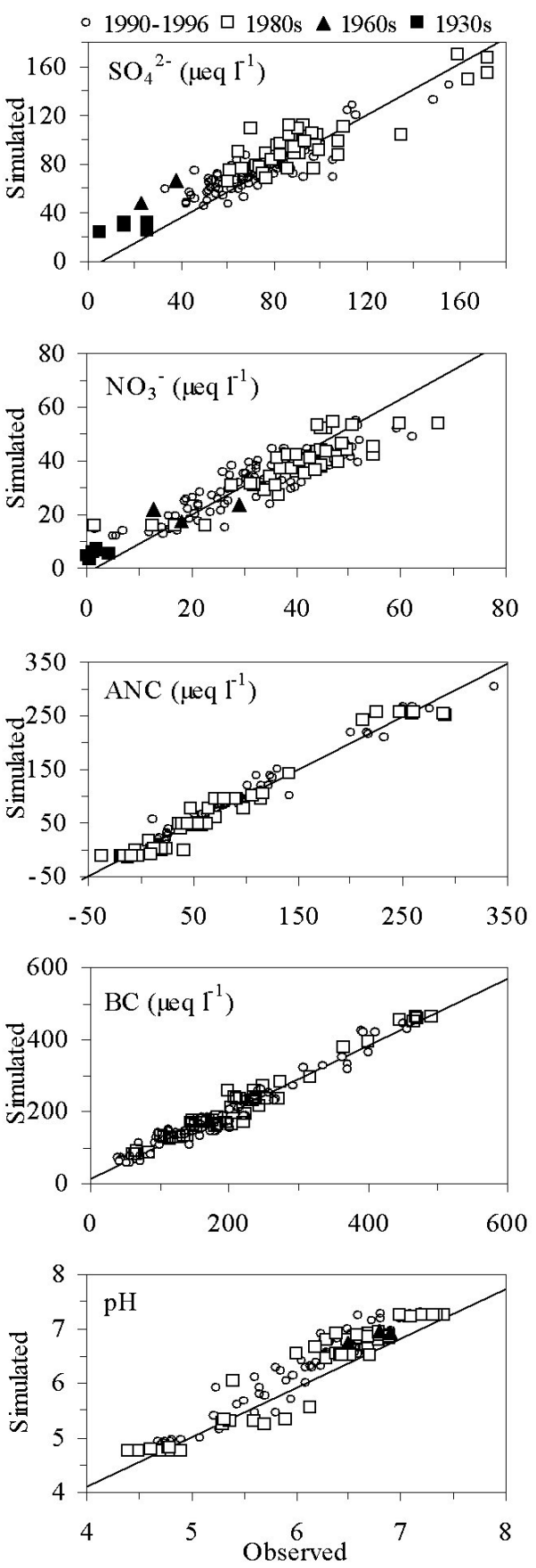

Fig. 2. Relationships between observed and simulated (MAGIC) concentrations of $\mathrm{SO}_{4}^{2-}, \mathrm{NO}_{3}^{-}$, ANC (Gran-alkalinity), base cations (BC), and $\mathrm{pH}$ in the Tatra Mountain lakes (Tab. 1) during the 1937-1996 period (data for calibration years 1997-2002 not shown). Solid lines: linear regressions; numbers of observations, 130-148; all $\mathrm{P}<0.001 ; \mathrm{R}^{2}$ values of $0.83,0.84,0.97,0.96$, and 0.92 for $\mathrm{SO}_{4}{ }^{2-}, \mathrm{NO}_{3}{ }^{-}, \mathrm{ANC}, \mathrm{BC}$, and $\mathrm{pH}$, respectively. 

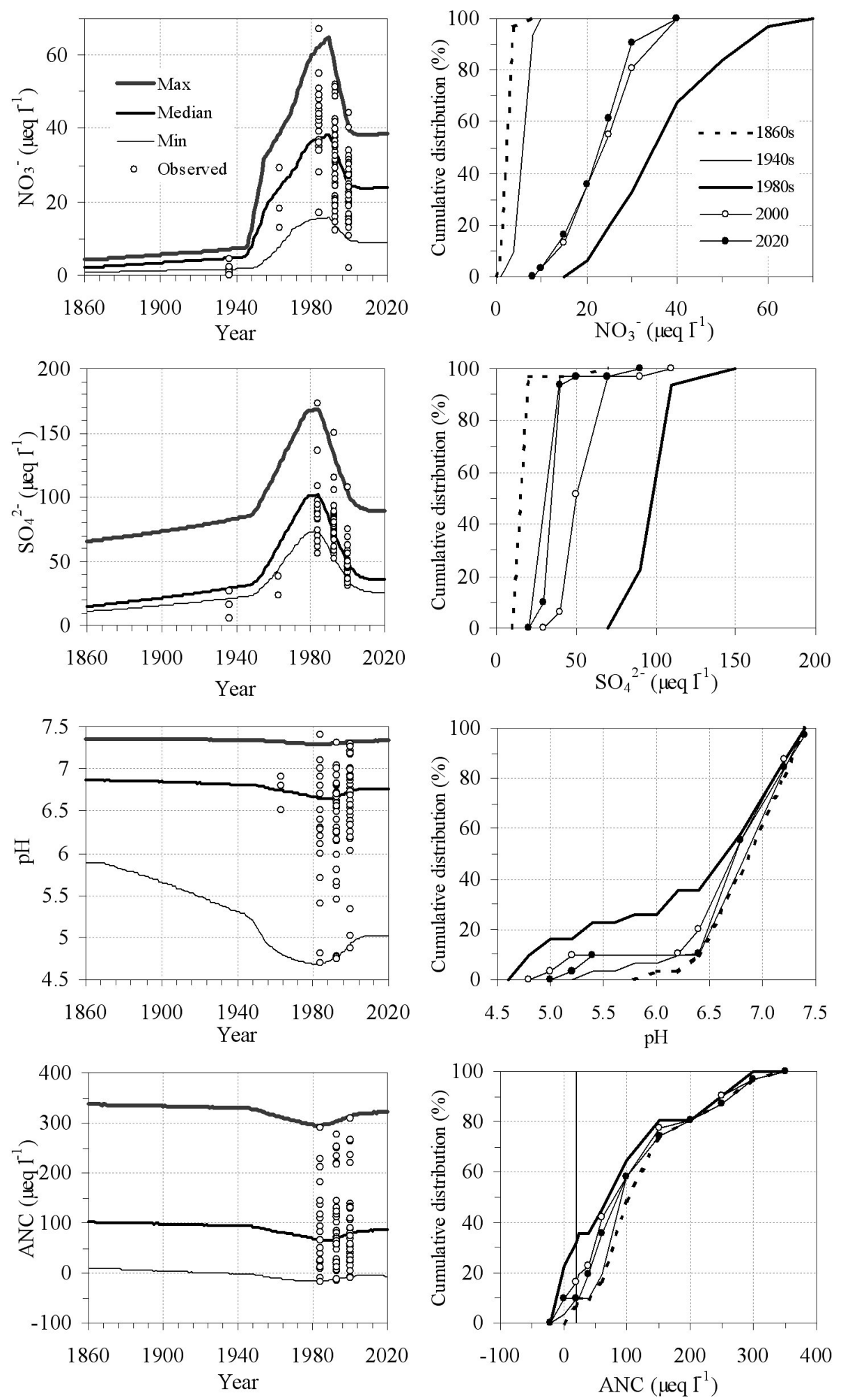

Fig. 3. Concentrations of $\mathrm{SO}_{4}{ }^{2-}, \mathrm{NO}_{3}{ }^{-}, \mathrm{pH}$, and $\mathrm{ANC}$ (Gran-alkalinity) in the Tatra Mountain lakes (Tab. 1) as simulated by MAGIC (Cosby et al. 2001). Left column: minimum (Min), median, and maximum (Max) simulated values (lines) and available observed data on the lakes under this study from 1937, 1963, middle 1980s, 1993-1994, and 2000 (open circles). Right column: Cumulative distribution of simulated values for the 1860s, 1940s, 1980s, 2000 and 2020. Solid line in the bottom figure represents ANC of 20 $\mu \mathrm{eq} \mathrm{l}^{-1}$. 
Tab. 5. Simulated (MAGIC) and measured $(*)$ median composition of the 31 selected Tatra Mountain lakes (Tab. 1). ANC, Gran-alkalinity; BC, base cations. Units, $\mu$ eq $1^{-1}$.

\begin{tabular}{lccccc}
\hline & $\mathrm{SO}_{4}{ }^{2-}$ & $\mathrm{Cl}^{-}$ & $\mathrm{NO}_{3}{ }^{-}$ & $\mathrm{ANC}$ & $\mathrm{BC}$ \\
\hline $1860 \mathrm{~s}$ & 16 & 3 & 2 & 101 & 124 \\
$1940 \mathrm{~s}$ & 31 & 3 & 6 & 94 & 136 \\
$1980 \mathrm{~s}$ & 100 & 8 & 37 & 68 & 208 \\
2000 & 50 & 4 & 24 & 79 & 161 \\
$2000^{*}$ & 52 & 4 & 26 & 80 & 161 \\
2020 & 35 & 4 & 24 & 85 & 149 \\
\hline
\end{tabular}

The observations showed that all the alpine Tatra Mountain lakes were seriously affected by acid deposition in the 1980s (Stuchlík et al. 1985; Kopáček \& Stuchlík 1994), with concentrations of $\mathrm{SO}_{4}{ }^{2-}$ and $\mathrm{NO}_{3}{ }^{-}$ higher on average by $66 \mu$ eq $1^{-1}$ and $30 \mu$ eq $\mathrm{l}^{-1}$, respectively, compared to 1937 (Stangenberg 1938). The simulated average increases in $\mathrm{SO}_{4}{ }^{2-}$ and $\mathrm{NO}_{3}{ }^{-}$concentrations during the same period agreed with those observed. This increase in SAA concentrations was accompanied by a widespread decline in lake water ANC and $\mathrm{pH}$. One third of the lake population had ANC $<20$ $\mu$ eq $1^{-1}$ and $23 \%$ of the lakes had a depleted carbonate buffering system and $\mathrm{pH}<5.5$ in the 1980 s (Fig. 3).

The deposition scenario used in this study was derived from emission trends of $\mathrm{S}$ and $\mathrm{N}$ compounds in central Europe (Kopáček et al. 2001) and was checked using long term data on water composition of the Bohemian Forest lakes (Majer et al. 2003), situated 500 $\mathrm{km}$ west of the Tatra Mountains. The simulated $\mathrm{SO}_{4}{ }^{2-}$ concentrations, however, are higher than those observed in the early 1960s (Fig. 3). An even greater disproportion would result from the $\mathrm{S}$ deposition sequence provided by EMEP model (Schöpp et al. 2003). If the observed concentrations are correct, they indicate that the onset of strong acidification of the Tatra Mountain lakes was somewhat delayed but steeper than suggested by our modelling. The Tatra Mountain lakes are situated at a higher elevation and at a greater distance from the area of the maximum acid emissions than the Bohemian Forest and were thus probably exposed to increased depositions of pollutants later, after construction of taller smokestacks which released air pollution to higher layers of the atmosphere. The delay in acidification of the Tatra Mountain lakes (compared to the Bohemian Forest) was also suggested by the later extinction of zooplankton (Fott et al. 1994). The maximum acidification occurred similarly in both areas in 1977-1987.

Reversal of lake acidification started in the late 1980s and progressed rapidly throughout the 1990s (Fig. 3) due to $57 \%$ and $35 \%$ declines in deposition of $\mathrm{SO}_{4}{ }^{2-}$ and inorganic $\mathrm{N}\left(\mathrm{NO}_{3}-\mathrm{N}+\mathrm{NH}_{4}-\mathrm{N}\right)$, respectively, in the Tatra Mountains between the middle 1980s and 2000 (Fig. 1). Concentrations of SAA decreased by $66 \mu$ eq $1^{-1}$ (Tab. 5) during this period, and all lakes (except for TA0026) had $\mathrm{SO}_{4}{ }^{2-}$ concentrations $<70 \mu \mathrm{eq} \mathrm{l}^{-1}$ in 2000
(Fig. 3). $\mathrm{NO}_{3}{ }^{-}$concentrations decreased less $(\sim 35 \%$ on average) than $\mathrm{SO}_{4}{ }^{2-}(50 \%)$, and $\sim 55 \%$ of the lakes had $\mathrm{NO}_{3}^{-}$concentrations $<25 \mu \mathrm{eq} \mathrm{l}^{-1}$ in 2000 . The significant decline in $\mathrm{Cl}^{-}$concentrations (by $4 \mu \mathrm{eq} \mathrm{l}^{-1}$ on average) was similar to that observed in the nearby Czech mountain areas and was probably associated with a decline in $\mathrm{Cl}$ emissions (mostly as $\mathrm{HCl}$ ) from industrial sources in the Czech Republic and Slovakia (Veselý et al. 2002).

As a response to decreasing SAA concentrations, ANC and $\mathrm{pH}$ increased significantly, and the lake population with ANC $<20 \mu \mathrm{eq}^{-1}$ decreased to $\sim 16 \%$ (Fig. 3).

Model results indicate that full implementation of the Gothenburg Protocol (UN-ECE 1999) in Central Europe will produce only relatively small additional improvements of air quality in the Tatra Mountains compared to the status in 2002 (Fig. 1). Around 2010, the $\mathrm{SO}_{4}{ }^{2-}, \mathrm{NH}_{4}^{+}$, and $\mathrm{NO}_{3}^{-}$deposition in the Tatra Mountains (51, $18 \mathrm{meq} \mathrm{m}^{-2} \mathrm{y}^{-1}$, and 45 meq m${ }^{-2} \mathrm{y}^{-1}$ respectively) would be at levels comparable to those in the $1950 \mathrm{~s}$. Nevertheless, water quality will continue to recover due to decreasing release of $\mathrm{S}$ stored in the soils and a slow replenishment of base cation pools in the soils.

The release of all S accumulated in the Tatra Mountain soils over the last seven decades can be expected within $\sim 20$ years at the current rates of $\mathrm{S}$ deposition and $\mathrm{SO}_{4}{ }^{2-}$ leaching (Kopáček et al. 2001). Lake $\mathrm{SO}_{4}{ }^{2-}$ concentrations (30-40 $\mu \mathrm{eq} \mathrm{I}^{-1}$ in $80 \%$ of lakes; Fig. 3) will be comparable to that in deposition around 2020, suggesting a future steady state condition in the $\mathrm{S}$ input and output from the catchment-lake ecosystems. The additional decline in SAA concentrations will lead to further recovery of lakes and only $10 \%$ of lakes will have ANC $<20 \mu$ eq $1^{-1}$. However, the simulated data suggest that the original carbonate buffering system of these lakes will not yet be re-established. The water quality (with the exception of higher $\mathrm{NO}_{3}{ }^{-}$concentrations) should be comparable to that in the 1940s-1950s (Fig. 3).

In our previous studies we assumed that the increase in concentrations of SAA during the acidification phase was compensated predominantly by the decrease in $\mathrm{HCO}_{3}{ }^{-}$concentrations (Kopáček \& Stuchlík 1994). A potential change in concentrations of other ions was neglected due to the absence of reliable data on BC concentrations before the 1980s. However, the extent of changes in concentrations of $\mathrm{BC}, \mathrm{HCO}_{3}^{-}, \mathrm{Al}^{\mathrm{n}+}$ and $\mathrm{H}^{+}$ during the lake water reversal from acidification (Kopáček et al. 2002), as well as dynamic modelling in this study, has shown that the response of water chemistry to the elevated SAA loading was more complex. The modelled total average increase in SAA concentrations in the lakes over the $1860-1980$ s period $(122 \mu \mathrm{eq}$ $\mathrm{l}^{-1}$ ) was predominantly compensated for by the increase in $\mathrm{BC}(63 \%), \mathrm{H}^{+}$and $\mathrm{Al}^{\mathrm{n}+}(2 \%$ each), while the decline in $\mathrm{HCO}_{3}{ }^{-}$concentrations was less important $(34 \%$ or 41 $\mu$ eq $1^{-1}$ on average). Similarly, the average decline in 
SAA concentrations $\left(80 \mu \mathrm{eq}^{-1}\right)$ during the lake recovery period (1980s-2020) has been compensated for predominantly by the decline in concentrations of $\mathrm{BC}$ $(68 \%), \mathrm{H}^{+}$and $\mathrm{Al}^{\mathrm{n}+}$ (3\% and $2 \%$, respectively) and the increase in $\mathrm{HCO}_{3}{ }^{-}$concentrations $\left(28 \%\right.$ or $23 \mu \mathrm{eq} \mathrm{l}^{-1}$ on average). A similar water chemistry response to acidification and recovery was also observed in other European lake-districts (e.g., Evans et al. 2001) and is consistent with theoretical prognoses (Reuss \& Johnson 1986).

\subsection{Lake-to-lake variations in the region}

The response of chemical composition of individual lakes to the changes in acid deposition was not uniform within the lake district but differed significantly among the lakes, reflecting predominantly their catchment characteristics and acid-base status. The acid-base status of the lakes in the 1980s (Fott et al. 1994) was used to divide the lakes into three main categories of sensitivity to acidification (Tab. 1): non-sensitive (NS) lakes ( $\mathrm{pH}$ $>6$, ANC $>25 \mu \mathrm{eq}^{-1}$ ); acid-sensitive (AS) lakes $(5<\mathrm{pH}$ $<6$, ANC 0-25 $\mu$ eq $1^{-1}$ ); and extremely sensitive (ES) lakes $\left(\mathrm{pH}<5, \mathrm{ANC}<0 \mu \mathrm{eq} \mathrm{I}^{-1}\right)$.

In contrast to $\mathrm{SO}_{4}{ }^{2-}$ and $\mathrm{Cl}^{-}$, which exhibited similar trends in all lake categories (Fig. $5 \mathrm{~F}, \mathrm{Cl}^{-}$not shown), the changes in atmospheric deposition of inorganic $\mathrm{N}$ had the greatest impact on $\mathrm{NO}_{3}{ }^{-}$concentrations in the AS lakes (Fig. 4). The increase in $\mathrm{NO}_{3}{ }^{-}$concentrations in these lakes (both observed and simulated) was higher than the increase in atmospheric deposition of $\mathrm{NO}_{3}{ }^{-}$over the period 1860-1980, indicating that part of the deposited $\mathrm{NH}_{4}{ }^{+}$(or alternatively, an equivalent amount of mineralised soil organic N) was nitrified in soils and leached from the catchments. The catchments of AS lakes have the lowest percentage of meadows $(27 \%)$ and sparse soils $36 \pm 15 \mathrm{~kg} \mathrm{~m}^{-2}$, while the catchments of NS and ES have significantly larger amounts of soil $(49 \pm 13$ and $74 \pm 24 \mathrm{~kg} \mathrm{~m}^{-2}$, respectively; Table 2). The ability of alpine catchments to retain $\mathrm{N}$ is positively related to vegetation and amount of soil (e.g., Baron et al. 1994; Williams et al. 1996; Kopáček et al. 2000). The sparse vegetation and low amount of soil thus explain the low terrestrial retention of $\mathrm{N}$ in the AS catchments, resulting in the highest $\mathrm{NO}_{3}{ }^{-}$(and, consequently, also SSA) concentration in these lakes compared to the other categories (Fig. 5E, G).

Categories of NS and AS lakes have had similar soil base saturation throughout the study period (Fig. 5D). The higher amount of soil in the NS catchments means that these catchments have a larger base cation exchange pool compared to the AS catchments. Thus, soil exchange processes in the NS catchments retain more $\mathrm{H}^{+}$from atmospheric deposition and biological $\mathrm{NH}_{4}^{+}$ transformations, while more protons are leached into the AS lakes. Moreover, the simulations indicate that the NS catchments have higher weathering rates than the AS catchments (229 vs 107 meq $\mathrm{m}^{-2} \mathrm{y}^{-1}$ on average), which further contributes to the higher $\mathrm{H}^{+}$retention by weathering within the NS catchments. The changes in acid deposition were thus predominantly compensated for by changes in $\mathrm{BC}$ concentrations $(\sim 75 \%)$ in $\mathrm{NS}$ lakes, while mostly by the inverse changes in $\mathrm{HCO}_{3}{ }^{-}$ concentrations $(>50 \%)$ in AS lakes (Fig. 4). Consequently, the combination of morphological (soil pool) and physical-chemical (weathering rate) characteristics predisposed the dramatic changes in $\mathrm{pH}$ and $\mathrm{ANC}$ in the AS lakes (Fig. 5A, B).

The carbonate buffering system of some of the AS lakes was depleted in the 1980s (e.g., TA0017, Kopáček et al. 2002, 2003) and replaced by an Al buffering system (Fig. 5H). The transparency of the TA0017 lake was substantially higher under the acid conditions compared to its current levels ( $>17 \mathrm{~m}$ vs 5-6 m; unpubl. data). We can only hypothesise whether the high transparency was caused by coagulation of DOC (Steinberg 1991), increased DOC photoreactivity under more acid conditions (Anesio \& Granéli 2003), or resulted mostly from lower concentrations of chlorophyll- $a$ in the $1980 \mathrm{~s}$ compared to their current levels (Stuchlík, unpubl. data). Answering this question has a crucial impact for understanding the processes of biological recovery of the Tatra Mountain lakes after their chemical reversal from acidification.

The most pronounced acidification has occurred in the ES lakes even though these lakes were exposed to lower SAA input from catchments than other lake categories due to the biggest soil pools and, consequently, lowest $\mathrm{NO}_{3}^{-}$leaching (Fig. 5E, G). While the simulated $\mathrm{pH}$ values were stable in the NS and AS lakes before the $1950 \mathrm{~s}, \mathrm{pH}$ declined steadily in the ES lakes already in the 1860-1950 period, after which their carbonate buffering systems were depleted (Fig. 5B) and $\mathrm{pH}$ rapidly declined below 5.0 (Fig. 5A). Compared to the AS lakes, acidification of the ES lakes was mitigated to a lesser extent by $\mathrm{H}^{+}$neutralisation with $\mathrm{HCO}_{3}^{-}$anions, due to lower background ANC. In addition, the changes in SAA concentrations were compensated to a lesser extent by an increase in $\mathrm{BC}$ concentrations than in the NS lakes (Fig. 4) despite the bigger catchment soil pools.

The ES catchments have lower base saturation and lower simulated weathering rates $\left(37 \mathrm{meq} \mathrm{m} \mathrm{m}^{-2}\right.$ on average) than the NS and AS catchments (Tab. 2; Fig. 5D). The reason behind this difference is still unclear, and may be associated with the presence of easily weatherable rocks in some catchments despite their dominant granodioritic composition; Kopáček et al. 2004). The ES lakes also have the lowest catchment-tolake area ratios (Tab. 1) and, consequently, the lowest ANC input from terrestrial sources (e.g., Schindler 1986). During the acidification phase, BC export from the ES catchments was lower than the total BC input by weathering and atmospheric deposition (e.g., 101 vs 114 meq $\mathrm{m}^{-2} \mathrm{y}^{-1}$ on average, in the 1980s) and BC was accumu- 

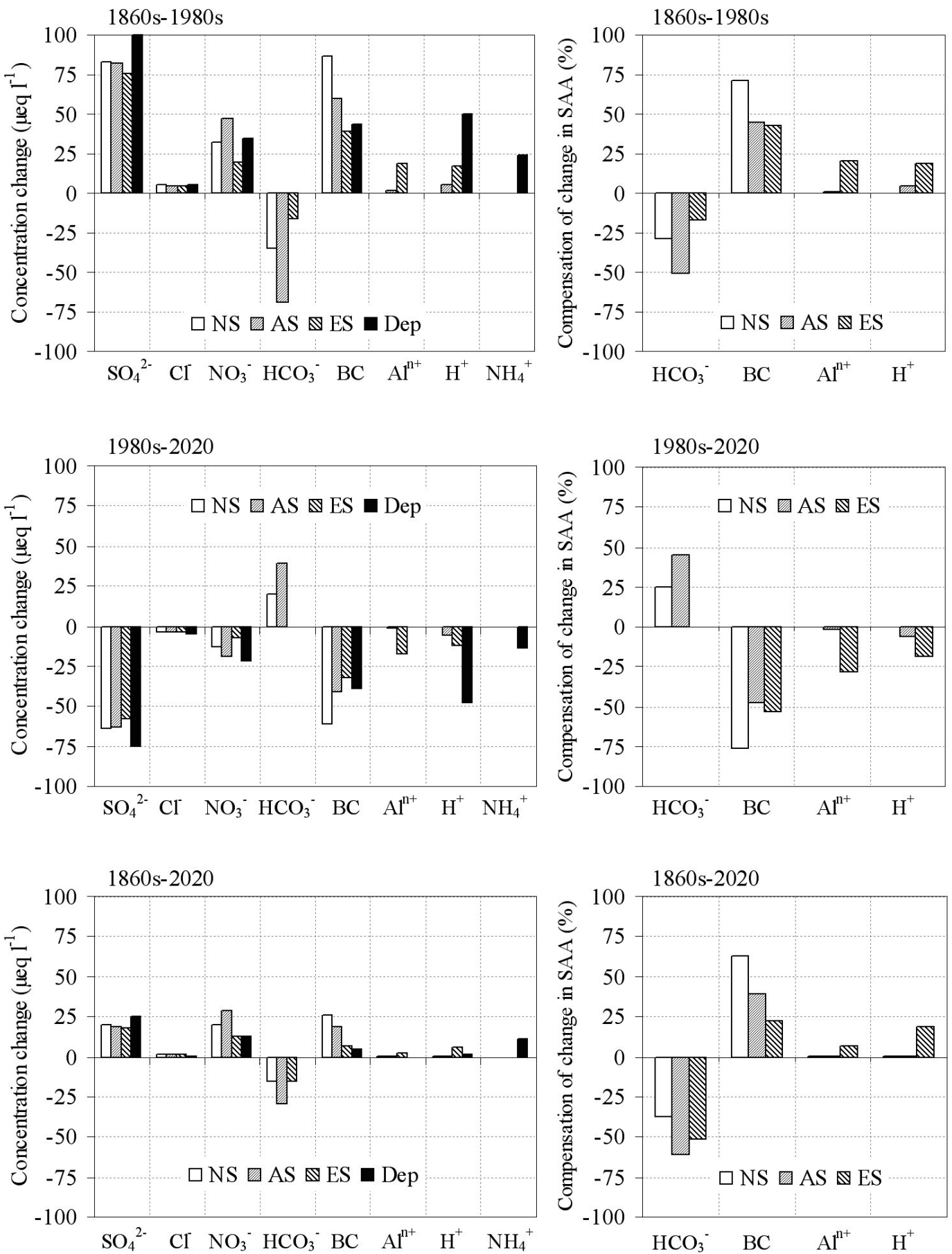

Fig. 4. Changes in chemical composition of the Tatra Mountain lakes (Tab. 1) during the acidification phase (1860s-1980s), recovery phase (1980s-2020), and over the whole study period (1860s-2020) as simulated by MAGIC (Cosby et al. 2001). Left column: average changes in ionic composition of the three lake categories (NS, non-sensitive; AS acid sensitive; and ES, extremely sensitive) and atmospheric deposition (Dep). Right column: average relative changes in lake water composition compensating for the changes in concentrations of strong acid anions (SAA). BC, base cations.

lated in the soils, increasing their base saturation (Fig. 5D). This phase of $\mathrm{BC}$ accumulation in soils was most pronounced in the catchment of lake TA0107 while only moderate for TA0047 (Kopáček et al. 2003), and resulted from the elevated $\mathrm{BC}$ deposition (Fig. 1). Be- cause the change in SAA deposition was larger than that of $\mathrm{BC}$, the net effect was a decline in ANC despite the increase in soil base saturation. Moreover, the $\mathrm{BC}$ removed from precipitation by cation exchange adsorption during water passage through the soil profile were re- 

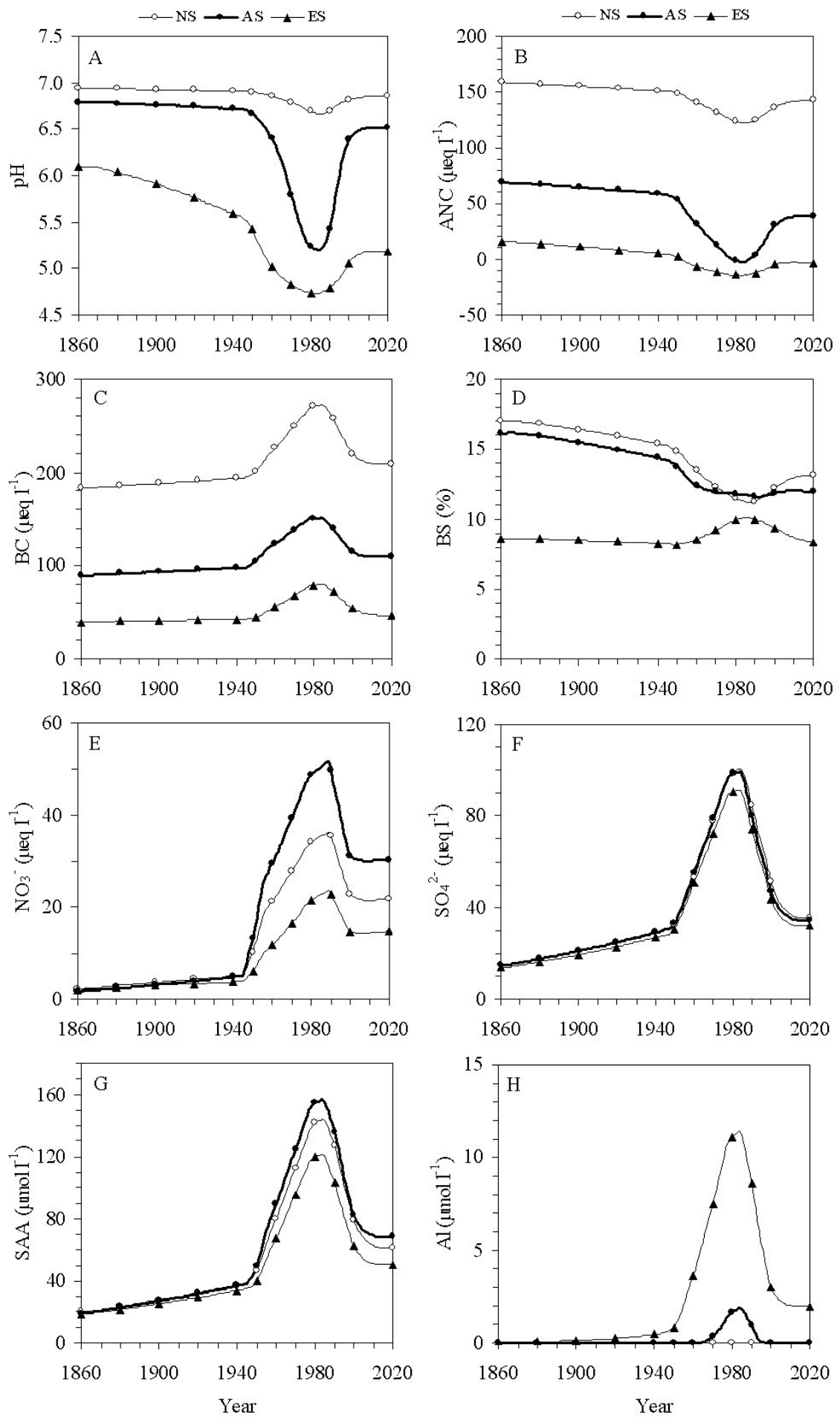

Fig. 5. Average trends in water composition of the three lake categories (NS, non-sensitive; AS acid-sensitive; and ES, extremely sensitive) in the Tatra Mountains as simulated by MAGIC (Cosby et al. 2001). ANC (Gran-alkalinity); BS, base saturation of soils; $\mathrm{BC}$, base cations; SAA, strong acid anions.

placed by $\mathrm{H}^{+}$and $\mathrm{Al}$ de-sorbed from the soils, increasing terrestrial export of acidity into the lakes (Fig. 5A, $\mathrm{H})$. In the $1980 \mathrm{~s}$, the elevated $\mathrm{H}^{+}$and $\mathrm{Al}$ concentrations compensated for $\sim 20 \%$ each of the increase in SAA concentrations in the ES lakes (Fig. 4). We assume that the elevated $\mathrm{BC}$ deposition into ES catchments with low soil base saturation had an effect on water acidification similar to that observed by Wright et al. (1988) after experimental addition of sea salts to acidic soils. 
After the rapid decline in emissions of particulates in central Europe ( $>80 \%$ during the $1980-2000$ period; Kopáček et al. 2002) the deposition of BC significantly declined (e.g., Hedin et al. 1994). In 2000, the ES catchments were in steady state conditions with respect to the $\mathrm{BC}$, with $\mathrm{BC}$ output (69 meq $\mathrm{m}^{-2} \mathrm{y}^{-1}$ ) equalling the $\mathrm{BC}$ supply by weathering and atmospheric deposition (70 meq $\left.\mathrm{m}^{-2} \mathrm{y}^{-1}\right)$. The model predicts a change in these steady state conditions in the future (Fig. 5D) due to continuing decline in $\mathrm{BC}$ deposition and a potential increase in $\mathrm{NH}_{4}{ }^{+}$deposition (Fig. 1).

Current levels in $\mathrm{NH}_{3}$ emissions in Central Europe are already below the Gothenburg limit (UN-ECE 1999) due to the lowered agriculture production in the area of Poland, Slovakia, and Czech Republic in the 1990s (Kopáček et al. 2001). Under the assumption that $\mathrm{NH}_{4}{ }^{+}$ emissions will increase in Central Europe, a slow increase in $\mathrm{NO}_{3}{ }^{-}$concentrations can be expected in all lake categories. At the same time deposition of $\mathrm{BC}$ will decline, and together these two factors will cause the soils of ES catchments to acidify. At the NS and AS catchments, on the other hand, the expected conditions should be sufficient for the slow recovery of soil base saturation (Fig. 5D) due to higher weathering rates.

Besides the uncertainty associated with future $\mathrm{NH}_{3}$ emissions, the model forecasts of lake water chemistry can be influenced by uncertainty in future change in catchment ability to retain N. In this study we assume no significant climatically- or chemically-derived changes in soil N-cycling in the 2002-2020 period which would affect the current levels of terrestrial $\mathrm{NO}_{3}{ }^{-}$ leaching. Nevertheless, such changes cannot be fully excluded, because $\mathrm{N}$ utilisation within the Tatra Mountain catchments significantly decreased after the $1950 \mathrm{~s}$ (Kopáček et al. 2001). The changes in $\mathrm{NO}_{3}{ }^{-}$leaching would significantly affect prognoses for water and soil chemistry in the ES catchment-lake ecosystems, but also in the AS lakes, where $\mathrm{NO}_{3}{ }^{-}$should represent $45 \%$ on average of the SAA pool in 2020 (Fig. 5). In contrast, the potentially altered $\mathrm{NO}_{3}{ }^{-}$leaching would have only limited impact on the overall lake chemistry in the NS lakes.

Among the 31 lakes selected for this study 22, 6, and 3 belonged to the NS, AS and ES categories, respectively. The proportion of individual categories was similar also for the total population of all 84 alpine Tatra Mountain lakes $>0.1$ ha $(49,28$, and 7 , respectively), with the exception of the AS lakes, the proportion of which was somewhat higher (30\% vs 20\%). Consequently, the results based on the selected 31 lakes are reasonably applicable for the whole alpine zone of the Tatra Mountains.

\section{CONCLUSIONS}

The MAGIC model was successfully calibrated for all 31 lakes selected in this study to represent alpine zone of the Tatra Mountains. The lake water chemistry exhibited significant changes during both the acidification (1860 to 1980 s) and recovery (1980s to 2020) phases. In general, the changes in lake concentrations of SAA were compensated for by declines in $\mathrm{HCO}_{3}{ }^{-}$and increases in $\mathrm{BC}, \mathrm{H}^{+}$, and $\mathrm{Al}^{\mathrm{n}+}$ concentrations, but the extent of these changes differed among the lakes. While concentrations of $\mathrm{SO}_{4}{ }^{2-}$ and $\mathrm{Cl}^{-}$exhibited similar trends in all lake categories, reflecting predominantly their trends in atmospheric deposition, concentrations of other ions were determined or significantly modified by catchment characteristics such as soil pools, soil base saturation, weathering rates, and in-lake processes.

These catchment characteristics place the lakes into 3 categories of sensitivity to acidification (non-sensitive, sensitive, and extremely sensitive). Lakes in these categories became non-acidified, acidified, and strongly acidified, respectively, in the 1980s. Each category displayed a different response. Lakes with a high weathering rate and soil $\mathrm{BC}$ exchangeable capacity had higher ANC before the onset of acidification, and their $\mathrm{pH}$ was resistant to changes in atmospheric deposition chemistry. These lakes remained non-acidified even in the 1980s. Sensitive lakes showed dramatic pH changes both during the acidification and recovery phases. The sensitivity of these lakes resulted from intermediate weathering rates and sparse soils (and/or alpine meadows) in their catchments. The small soil pool (i) was a reason for low soil exchangeable $\mathrm{BC}$ capacity (less $\mathrm{H}^{+}$ was retained in the soils) and (ii) resulted in the lower retention of atmospherically deposited $\mathrm{N}$ in the catchment and, consequently, in the elevated terrestrial $\mathrm{NO}_{3}{ }^{-}$ (and SAA) export. These lakes temporarily lost their carbonate buffering system in the 1980s. The sensitivity of extremely sensitive lakes resulted mostly from very low weathering rates and soil base saturation, and these lakes have been strongly acidified (with a depleted carbonate buffering system) since the 1950s.

The 2020 forecast based on the scenarios of acid deposition expected according to the Gothenburg Protocol indicates that despite the pronounced improvement in the lake water quality since the 1980 s, the SAA concentrations should be still elevated by $30-49 \mu \mathrm{eq} \mathrm{l}^{-1}$ (averages for individual lake categories) compared to background levels. These conditions will not be sufficient for the re-establishment of the carbonate buffering system in extremely sensitive lakes.

The full implementation of the Gothenburg Protocol should bring a stable chemical reversal from acidification for $\sim 90 \%$ of the Tatra Mountain lakes. This situation is not unique to the Tatra Mountains, as some percentage of lakes in Central England (South Pennines), the southern Alps, southern Norway, and southern Sweden are also predicted to not return to their pre-acidification chemistry under proposed emission levels (Jenkins et al. 2003). A further decrease in European $\mathrm{S}$ or $\mathrm{N}$ emissions would be needed for the recovery of the most sensitive Tatra Mountain lakes. 


\section{ACKNOWLEDGMENTS}

The primary data on soil, water, and deposition chemistry were collected within projects EMERGE (Environment Project of European Commission; EVK1CT-1999-00032), Institutional Research Plan ASCR No. Z 6017912, and MSM 123100004, and were evaluated within RECOVER:2010 project (Environment Project of European Commission; EVK1-99-00018).

\section{REFERENCES}

Anesio, A.M. \& W. Granéli. 2003. Increased photoreactivity of DOC by acidification: Implications for the carbon cycle in humic lakes. Limnol. Oceanogr., 48(2): 735-744.

Baron, J.S., D.S. Ojima, E.A. Holland \& W.J. Parton. 1994. Analysis of nitrogen saturation potential in Rocky Mountain tundra and forest: implications for aquatic systems. Biogeochemistry, 27: 61-82.

Bombówna, M. 1965. Hydrochemical investigations of the Morskie Oko lake and the Czarny staw lake above the Morskie Oko in the Tatra Mountains. In: K. Starmach (Ed.), Limnological Investigations in the Tatra Mountains and Dunajec River Basin, Komitet Zagospodarzovania Ziem Górskych, Polish Academy of Sciences, Kraków. Zeszyt No 11: 7-11.

Bombówna, M. \& K. Wojtan. 1996. Temporal changes in the water chemistry of the Tatra lakes. In: Z. Krzan (Ed.), Przyroda Tatrzanskiego Parku Narodovego a Czlowiek, Tom 3, Wplyw czlowieka, TPN, Kraków-Zakopane, Poland: 56-59 (In Polish).

Chomitz, K. \& F. Šamaj. 1974. Zrážkové pomery (Precipitation characteristics). In: M. Konček et al. (Eds), Klíma Tatier, VEDA, Bratislava: 443-536 (In Slovak).

Cosby, B.J., R.C. Ferrier, A. Jenkins \& R.F. Wright. 2001. Modelling the effects of acid deposition: refinements, adjustments and inclusion of nitrogen dynamics in the MAGIC model. Hydrol. Earth Syst. Sci., 5(3): 499-517.

Driscoll, C.T. 1984. A procedure for the fractionation of aqueous aluminum in dilute acidic waters. Intern. J. Environ. Anal. Chem., 16: 267-284.

Evans, C.D., J.M. Cullen, C. Alewell, A. Marchetto, F. Moldan, J. Kopáček, A. Prechetel, M. Rogora, J. Veselý \& R.F. Wright. 2001. Recovery from acidification in European surface waters. Hydrol. Earth Syst. Sci., 5(3): 283297.

Hedin, L.O., L. Granat, G.E. Likens, T.A. Buishand, J.N. Galloway, T.J. Butler \& H. Rodhe. 1994. Steep declines in atmospheric base cations in regions of Europe and North America. Nature, 367: 351-354.

Fott, J., M. Pražáková, E. Stuchlík \& Z. Stuchlíková. 1994. Acidification of lakes in Šmava (Bohemia) and in the High Tatra Mountains (Slovakia). Hydrobiologia, 274: $37-$ 47.

Henriksen, A., W.A. Mill, M. Kot, D. Rzychon \& B.M. Wathne. 1992. Critical load of acidity to surface waters: A case study from the Polish Tatra Mountains. Report 29/1992, NIVA, Oslo: $34 \mathrm{pp}$.

Jenkins, A. 1999. End of the acid reign? Nature, 401: 537-538.

Jenkins, A., L. Camarero, B.J. Cosby, R.C. Ferrier, M. Forsius, R.C. Helliwell, J. Kopáček, V. Majer, F. Moldan, M. Posch, M. Rogora, W. Schöpp \& R. Wright. 2003. A modelling assessment of acidification and recovery of European surface waters. Hydrol. Earth Syst. Sci., 7(4): 447-455.

Kaste, Ø. \& P.J. Dillon. 2003. Inorganic nitrogen retention in acid-sensitive lakes in southern Norway and southern Ontario, Canada - a comparison of mass balance data with an empirical N retention model. Hydrol. Process., 17: 2393 2407.
Kelly, C.A., J.W.M. Rudd, R.H Hesslein, D.W. Schindler, P.J. Dillon, C.T. Driscoll, S.A. Gherini \& R.E. Hecky. 1987. Prediction of biological acid neutralisation in acid-sensitive lakes. Biogeochemistry, 3: 129-140.

Kopáček, J. \& E. Stuchlík. 1994. Chemical characteristics of lakes in the High Tatra Mountains, Czechoslovakia. Hydrobiologia, 274: 49-56.

Kopáček, J., J. Veselý \& E. Stuchlík. 2001. Sulphur and nitrogen fluxes and budgets in the Bohemian Forest and Tatra Mountains during the Industrial Revolution (1850-2000). Hydrol. Earth Syst. Sci., 5(3): 391-405.

Kopáček, J., E. Stuchlík, V. Straškrabová \& P. Pšenáková. 2000. Factors governing nutrient status of mountain lakes in the Tatra Mountains. Freshwater Biol., 43: 369-383.

Kopáček, J., B.J. Cosby, V. Majer, E. Stuchlík \& J. Veselý. 2003. Modelling Reversibility of Central European Mountain Lakes from Acidification: Part II - The Tatra Mountains. Hydrol. Earth Syst. Sci., 7(4): 510-524.

Kopáček, J., J. Kaňa, H. Šantrǔčková, T. Picek \& E. Stuchlík. (2004). Chemical and biochemical characteristics of alpine soils in the Tatra Mountains and their correlation with lake water quality. Water Air Soil Pollut., 153: 307-327.

Kopáček, J., E. Stuchlík, J. Veselý, J. Schaumburg, I.C. Anderson, J. Fott, J. Hejzlar \& J. Vrba. 2002. Hysteresis in reversal of Central European mountain lakes from atmospheric acidification. Water Air Soil Pollut., Focus, 2: 91114.

Lajczak, A. 1996. Hydrologia (Hydrology). In: Z. Mirek, Z. Głowaciński, K. Klimek \& H. Piękoś-Mirkowa (Eds), Przyroda Tatrzańskiego Parku Narodowego. Tatrzański Park Narodowy, Zakopane-Kraków: 169-196 (in Polish).

Lydersen, E., D. Rzychon, A. Worsztynowicz, K. Torseth K., J.E. Hanssen, W.A. Mill, M. Kot, A. Henriksen \& B.M. Wathne. 1997. Critical loads of acidity to lakes in the Polish Tatra Mountains-Final report. Report 44/1997, NIVA, Oslo: $49 \mathrm{pp}$.

Majer, V., B.J. Cosby, J. Kopáček \& J. Veselý. 2003. Modelling Reversibility of Central European Mountain Lakes from Acidification: Part I - The Bohemian Forest. Hydrol. Earth Syst. Sci., 7(4): 494-509.

Nemčok, J., V. Bezák, M. Janák, Š. Kahan, W. Ryja, M. Kohút, I. Lehotský, J. Wieczorek, J. Zelman, J. Mello, R. Halouzka, W. Raczkowski \& P. Reichwalder. 1993. Explanation of the Geological map of the Tatra Mountains, Geologický ústav Dionýza Štúra, Bratislava: 135 pp. (in Slovak).

Reuss, J.O. \& D.W. Johnson. 1986. Acid Deposition and the Acidification of Soil and Waters. Ecological Studies 50. Springer-Verlag, New York: $119 \mathrm{pp}$.

Schindler, D.W. 1986. The significance of in-lake alkalinity production. Water Air Soil Pollut., 30: 931-944.

Schöpp, W., M. Posch, S. Mylona \& M. Johansson. 2003. Long-term development of acid deposition (1880-2030) in sensitive freshwater regions in Europe. Hydrol. Earth Syst. Sci., 7(4): 436-446.

Stangenberg, M. 1938. Zur Hydrochemie der Tatraseen. Verh. Int. Verein. Limnol., 8: 211-220.

Steinberg, C. 1991. Fate of organic matter during natural and anthropogenic lake acidification. Wat. Res., 25: 14531458.

Stuchlík, E., P. Appleby, P. Bitušík, C. Curtis, J. Fott, J. Kopáček, M. Pražáková, N. Rose, O. Strunecký \& R.F. Wright. 2002. Reconstruction of long-term changes in lake water chemistry, zooplankton and benthos of a small, acidified high-mountain lake: MAGIC modelling and palaeolimnological analysis. Water Air Soil Pollut., Focus, 2: 127-138.

Stuchlík, E., Z. Stuchlíková, J. Fott, L. Růžička \& J. Vrba. 1985. Effect of acid precipitation on waters of the TANAP territory. Treatises concerning the Tatra National Park, 26: 173-211 (In Czech). 
The MOLAR Chemistry Group. 1999. The MOLAR project: atmospheric deposition and lake water chemistry. $J$. Limnol., 58: 88-106.

UN-ECE. 1999. Strategies and Policies for Air Pollution Abatement. Economic Commission for Europe (ECE.EB. AIR/65), Convention on Long-Range Transboundary Air Pollution, United Nations, New York and Geneva.

Veselý, J., V. Majer \& S.A. Norton. 2002. Heterogeneous response of central European streams to decreased acidic atmospheric deposition. Environ. Pollut., 120: 275-281.
Vološčuk, I. (Ed.). 1994. Tatra National Park (Tatranský národný park). Gradus, Slovakia: 551 pp. (in Slovak).

Williams, M.W., J.S. Baron, N. Caine, R. Sommerfeld \& R. Sanford, Jr. 1996. Nitrogen saturation in the Rocky Mountains. Environ. Sci. Technol., 30: 640-646.

Wright, R.F., S.A. Norton, D.F. Brakke \& T. Fronger. 1988. Experimental verification of episodic acidification of freshwaters by sea salts. Nature, 334: 422-424. 